\title{
CUMPRIMENTO DE SENTENÇA: EXECUTIVIDADE 'LATO SENSU' OU CONDENAÇÃO ESPECIAL?
}

\author{
Alessandro Rostagno*
}

\section{A proposta da nova reforma do Código de Processo Civil}

Com o advento da nova lei n. 11.232/05, que estabeleceu a fase de cumprimento das sentenças no processo de conhecimento e revogou dispositivos relativos à execução fundada em título judicial, dando outras providências, os operadores do direito se depararam com uma nova sistemática de efetivação da execução de títulos executivos judiciais, até então não empregada genericamente no sistema processual civil brasileiro, ao menos, no que diz respeito à busca da satisfação do direito material consignado em decisões jurisdicionais definitivas que dispunham sobre a condenação de alguém a pagar quantia certa.

A tentativa do legislador de reformular o tão atravancado procedimento de execução por quantia certa contra devedor solvente adveio dos constantes reclamos da doutrina e da jurisprudência no sentido da total ineficácia da formatação processual até então aplicada.

Com efeito, a vestusta formatação processual fundada na dualidade processual (cognição precedida de execução), que remonta à época romana, vinculada à idéia da necessidade de exercitar actio iudicati para cumprimento do decisum prolatado, não mais se adequava com outras parametrizações e construções legislativas modernas que permitiram, ao longo dos anos, a entrega do bem da vida no curso do mesmo procedimento, interpolando e combinando atos cognitivos e executivos em uma só relação processual, a exemplo dos procedimentos especiais e, logo após, das disposições contidas nos artigos 461 e 461-A do CPC inseridas no contexto processual com a reforma de 1995.

As técnicas legislativas consagradas naqueles procedimentos, e o estudo aprofundado da doutrina acerca da combinação de atos executivos e cognitivos, ou ainda até, cautelares, em um mesmo procedimento, trouxe o ideal de um processo sincrético, ou seja, um processo único, composto de várias fases e incidentes, mas que não permitiria a 
instauração de nova relação processual para dar cumprimento ao objeto jurídico reconhecido naquela que fora precedente.

Pelo contrário, na formatação sincrética, a tipologia do iter processual aponta para a evolução de uma seqüência de atos com natureza jurídica de finalidade diversa, ora cognitiva, ora executiva, ora até cautelar, mas jamais permitindo que qualquer efetivação ou cumprimento de decisão seja concretizada fora daquela mesma relação processual que reconheceu ou não o direito postulado.

Mas como classificar, sob a ótica da natureza jurídica, o provimento contido nessas espécies de tutela jurisdicional com base nos estudos doutrinários conhecidos?

Pontes de Miranda, em seu célebre estudo acerca da eficácia das decisões jurisdicionais, quando tenta efetivar uma classificação das sentenças, impõe uma análise sob a ótica de cinco eventuais eficácias que preponderantemente uma sentença poderia produzir.

Sob sua análise, de forma magnífica e profunda, ficou sedimentada na doutrina pátria (muito embora até hoje ainda existam aqueles que somente aceitam a classificação trinária) a noção de que as sentenças poderiam ter carga preponderantemente declaratória, constitutiva, condenatória, mandamental e 'executiva lato sensu'.

As três primeiras, com objeto definido pelo pedido apresentado em juízo, em vista de que se busca especificamente, o reconhecimento da existência ou inexistência de uma dada relação jurídica processual, ou de um fato, ou da criação, modificação ou extinção de uma dada situação jurídica, ou ainda, da necessidade de se exigir de alguém o cumprimento de uma obrigação, em vista da impossibilidade da obtenção do adimplemento voluntário, dado um facere, non facere ou derivada da entrega de coisa certa ou incerta, inclusive pagamento de soma em dinheiro.

Quanto às duas últimas formas (mandamentalidade e 'executividade lato sensu'), muito embora o ilustre jurista tenha tentado sistematizar ao máximo suas digreções acerca das técnicas diferenciadas consubstanciadas ora em uma ordem dirigida especificamente a alguém que deva ser cumprida por força da inevitabilidade da jurisdição e da infungibilidade da obrigação, ora por força da necessidade de se efetivar atos de sub-rogação praticados pelo Estado como forma complementar à decisão prolatada para a perfeita entrega do bem da vida na mesma relação processual, sem a necessidade de um processo autônomo de execução, tais técnicas passaram a ser adotadas ope legis, de forma casuística, passando a doutrina a divergir em vários pontos acerca das diferenças existentes entre ambas e delas perante a própria condenação 'stricto sensu'. 


\section{Executividade lato sensu, mandamentalidade e condenação}

Liebman, ao estudar a condenação, defendia a idéia de que a mesma, pura e simples, reconhecida em uma sentença, não teria eficácia executiva imediata, pois dependia de um 'plus', qual seja o início de um processo de execução autônomo, já que a mesma caracterizar-se-ia como preparatória à futura execução, ideal este fundado no vetusto mito da nulla executio sine titulo.

Assim sendo, a condenação não teria o caráter de exigir automaticamente o cumprimento da decisão prolatada, necessitando de atos subseqüentes exercitados em um processo posterior e autônomo, independente daquele onde foi formada a convicção de conhecimento que reconheceu a necessidade de que a parte cumpra a obrigação assumida e não adimplida voluntariamente.

Diante dessas observações, a técnica executiva lato sensu e a técnica mandamental se afastariam da condenação para assumir uma qualidade de independência da mesma a ponto de se constituírem formas específicas de prestação jurisdicional?

Entendemos que não, pois são estas técnicas as mesmas que são concretamente observadas como exemplos de efeitos jurídicos práticos derivados da condenação, pois ao se determinar uma ordem a alguém ou ao se impor atos de sub-rogação estatal para fins de complementação e conseqüente satisfação da decisão previamente obtida, nada mais se faz do que se empregar técnica processual específica voltada a uma melhor efetivação da obrigação reconhecida na decisão jurisdicional. ${ }^{1}$

\footnotetext{
${ }^{1}$ Para THEODOR JR., Humberto, Curso de Direito Processual Civil, v.1, Rio de Janeiro: Forense, 2000, p. 457, as peculiaridades vinculadas às sentenças mandamentais e executivas lato sensu "não são suficientes para criar sentenças essencialmente diversas, no plano processual, das três categorias clássicas. Tanto as que se dizem executivas como as mandamentais realizam a essência das condenatórias, isto é, declaram a situação jurídica dos litigantes e ordenam uma prestação de uma parte em favor da outra. A forma de realizar processualmente essa prestação, isto é, de executá-la, é que diverge. A diferença reside, pois, na execução e respectivo procedimento. Sendo assim, não há razão para admitir uma natureza diferente a tais sentenças. O procedimento em que a sentença se profere é que foge dos padrões comuns. Esse, sim, deve sr arrolado entre os especiais, pelo fato de permitir que numa só relação processual se reúnam os atos do processo de conhecimento e os do processo de execução. O procedimento é que merece a classificação de executivo 'lato sensu'ou 'mandamental' ”. Advogado em São Paulo-SP e Vitória-ES. Juiz do Tribunal de Impostos e Taxas da Secretaria da Fazenda do Estado de São Paulo (TIT/SP), com mestrado em direito processual civil pela Pontifícia Universidade Católica de São Paulo (PUC/SP). Presidente da Comissão Programa OAB vai à Faculdade da Ordem dos Advogados do Brasil - Seccional de São Paulo - SP. Professor coordenador de cursos de aperfeiçoamento da Associação de Advogados de São Paulo (AASP). Professor de Cursos de Pós
} 
Ou seja, são meios processuais de entrega mais rápida (e mais efetiva?) do bem da vida que inevitavelmente pertence àquele que saiu vitorioso na ação tida como condenatória e, que ao final, em uma sentença, reconhece a necessidade do cumprimento de uma obrigação, seja ela de entrega de coisa, de fazer, não-fazer e claro, também, de pagar quantia certa, espécie de obrigação de dar.

Assim sendo, executividade lato sensu e mandamentalidade são efeitos jurídicos derivados da condenação, e que ope legis podem encontram aplicabilidade na mesma relação processual ou fora dela, dependendo da política legislativa adotada.

As novas disposições contidas acerca da nova técnica legislativa lançada com a recente reforma processual, caracterizam, sem embargo, respeitadas as posições doutrinárias contrárias, claro mecanismo de efetivação da decisão condenatória prolatada em fase cognitiva e que, agora, dispensando processo executivo ex intervalo, permite que o jurisdicionado obtenha, mediante meios executivos diretos ou indiretos, aplicados de maneira complementar, dependendo do tipo de obrigação contida no conteúdo decisório, a possibilidade de ver efetivada sua pretensão relativa ao pedido inicial.

Uma obrigação, no plano do direito material, constitui-se em um liame existente entre sujeitos, sendo que de um lado se põe aquele que passa a ter o poder subjetivo de exigibilidade de uma prestação definida no aspecto objetivo de toda obrigação e de outro aquele que deverá adimplir a referida prestação, por força da lei ou da convenção a que se obrigou.

Se não cumprida a referida prestação, o devedor, por força de seu comportamento omissivo, gera a denominada crise de cooperação, produzindo-se o inadimplemento, ensejando assim, a necessidade de restauração (ou prevenção) do direito subjetivo violado ou ameaçado, pela sentença condenatória. ${ }^{2}$

De forma generalizada, tem se afirmado que o processo sincrético seria marcadamente fundado na técnica da executividade lato sensu, ou seja, na sistemática que engloba atos de cognição e de execução na mesma relação processual, e que a natureza jurídica da sentença prolatada seria diversa de uma sentença condenatória, pois nesta não haveria o chamado corte na base da legitimidade que a sentença de natureza executiva lato

Graduação Lato Sensu em direito processual civil, de direito processual tributário e professor convidado de diversas escolas de magistratura estaduais.

${ }^{2}$ Nesse sentido, a lição de Proto Pisani, Lezioni di diritto processuale civile, 3.ed., Napoli, Jovene, 1999, p. 34 
sensu ofertaria ao autor ou ao Réu no momento em que consigna em seu conteúdo disposição sobre a posse ou o direito relativo ao bem da vida pretendido.

Esta característica remontaria, segundo a melhor doutrina, por exemplo, a uma sentença possessória, em que o juiz reconhece na própria decisão a legitimidade da posse de uma partes (ao autor se procedente e ao réu se manifesta pela improcedência), permitindo ao mesmo, logo após o seu trânsito em julgado, na mesma relação processual, efetivar a referida decisão, através de atos de sub-rogação conseqüentes da decisão prolatada, para o obtenção de seu propósito, in casu, sendo expedido mandado de reintegração de posse em favor da parte caso não tenha havido cumprimento voluntário da decisão pois estar-se-ia restituindo ao verdadeiro e legítimo possuidor a sua condição jurídica que fora violada.

Houve execução autônoma? Não, mas simples atos de natureza executiva conseqüentes da decisão prolatada. Mas por quê? Por que assim quis o legislador, por força de política legislativa no que tange à proteção possessória.

Mas por que não estaríamos neste caso, diante de sentença condenatória? Somente pelo fato de que teria o juiz reconhecido a legitimidade da posse de uma das partes na sentença?

Ora, se o juiz reconhece a posse de alguém em sua decisão, está sem dúvida, antes de tudo, a perfazer atividade declaratória e quando determina a entrega desta posse por alguém, emite um comando que se delimita em uma obrigação.

Também assim, na mandamentalidade, que obriga a autoridade pública ou o ente particular a perfazer ou não determinado ato.

Qual a diferença entre ambas as sentenças? A de que em uma (mandamental) estaríamos diante de uma obrigação infungível e em outra (executiva lato sensu) de uma obrigação que pode ser substituída por atos se sub-rogação estatal, sendo nitidamente aqui, marcada pela fungibilidade.

Assim sendo, em ambas as hipóteses aponta o legislador em procedimentos diversos, a intenção de melhor tutelar estas obrigações, aplicando à decisão que as reconhece ou estabelece, meios eficazes de cumprimento, seja por vias diretas, como a ordem contida na mandamentalidade, seja, por atos de sub-rogação, sem execução autônoma, devolvendo ao vencedor sua condição jurídica até então violada, seja mediante atos expropriatórios 
expedidos pelo Estado-juiz em vista do não cumprimento voluntário a quem esta obrigação é vinculada. $^{3}$

Nesse sentido, em todos os casos, estamos diante de atividade condenatória, seguida de atos processuais que visam, através da atividade estatal, imprimir força de cumprimento, seja na esfera de direitos e até de liberdade da pessoa obrigada ou mediante expropriação patrimonial. ${ }^{4}$

Nítida intenção da lei em sempre evitar que as referidas obrigações convertam-se em perdas e danos, haja vista a impossibilidade fática de seu cumprimento.

\section{Cumprimento de sentença - uma condenação especial}

Transportando estas idéias à sistemática do cumprimento de sentença, estabelecido na forma da lei n. 11.232/05, podemos observar que o legislador no art. 475-J, e seus parágrafos subseqüentes, ao falar em condenação de obrigação de soma de dinheiro, cria mecanismos processuais que visa impedir a formação de uma execução autônoma, privilegiando a efetivação da decisão prolatada, na forma de complementá-la, na mesma relação processual, por atos subseqüentes que nitidamente imprimem maior agilidade e eficácia junto à decisão proferida.

Haveria aqui o chamado corte na base da legitimidade da parte que justificaria a natureza jurídica da sentença proferida como executiva lato sensu?

Ora, mesmo que o juiz ao final de sua decisão, explicite que desde já estaria o Réu obrigado a cumprir a obrigação de pagamento de soma em dinheiro consignada no

\footnotetext{
${ }^{3}$ Proto Pisani, op. cit., p. 161, sustenta que a tutela condenatória pode ser verificada tanto em um plano repressivo quanto em um plano preventivo, daí porque a referida tutela poderia ser efetivada em diversos sentidos de acordo com a pretensão postulada em juízo, seja com objetivo sub-rogatório, seja na forma da utilização de medidas de coerção, podendo ser impresso, assim, caráter executivo lato sensu ou mandamental aos efeitos da decisão prolatada, sem que se desnature a condição de condenatória da tutela prestada. Barbosa Moreira, ao tratar da questão, in Temas de Direito Processual: Oitava Série, São Paulo: Saraiva, 2004, p. 135, cita vários exemplos de tutelas de condenação que não correspondam a título executivo stricto sensu e, portanto, não aparelham processo de execução autônomo, como a sentença que condena à perda de sinal pago, a relativa à prestação futura de alimentos a serem descontados em folha de pagamento, as referentes as prestações de obrigações de fazer infungíveis. Em todas as sentenças, o credor se utilizará de medidas de coerção frente ao obrigado, mas nunca terá de valer-se de execução forçada a fim de obter a prestação que fora objeto da sentença condenatória.

${ }^{4}$ Segundo THEODORO JR., Humberto As novas Reformas do Código de Processo Civil, Rio de Janeiro: Forense, 2006, p. 127-128, não há distinção pelo objeto entre as sentenças ditas executivas e mandamentais diante da sentença condenatória, pois todas se referem "a acertamentos de direitos violados e sanções correspondentes. A diferença não estava no ato de sentenciar, mas apenas na forma de operar os efeitos condenatórios. Quando se classificavam as sentenças em declaratórias, constitutivas e condenatórias, sempre se levava em conta o objeto (o conteúdo do ato decisório). Já quando se cogitou das sentenças executivas ou mandamentais, o que se ponderou foram os efeitos de certas sentenças”.
} 
respectivo decisum, tal sentença não deixa de ser caracterizada como condenatória, pois o fato de existirem meios executivos posteriores à decisão que a complementem para uma melhor efetivação não caracteriza a existência de uma sentença que se distancia de uma condenação, pois aqui, temos verdadeira atividade executiva posterior à cognição por força de política legislativa.

A sentença que é proferida em sede de ação que visa condenação de soma em dinheiro é sem dúvida condenatória, e claro, por justificativas mais do que políticas e ideológicas, se passa a denominar-se de 'executiva lato sensu' para justificar um status quo diferenciado das demais decisões jurisdicionais permitindo assim maior efetividade.

Ora, quem disse que a sentença executiva lato sensu tem maior efetividade que a condenatória? Se admitirmos o conceito comum de condenação, sem dúvida tal circunstância se operará, mas se dotarmos a atividade condenatória de meios eficazes complementares à decisão prolatada, sem dúvida estaremos diante de formatação procedimental que muito se aproxima da hipótese executiva classificada por Pontes de Miranda, mas na análise do conteúdo da respectiva decisão, verificaremos que estamos diante de uma obrigação, e por suposto, de uma eficácia condenatória derivada do reconhecimento de que tal obrigação não fora cumprida, restando ao demandado se sujeitar aos atos expropriatórios estatais que se voltam ao ideal de entrega do bem da vida reconhecido ao vencedor na esfera cognitiva.

Tais provimentos, no entender da doutrina são caracteristicamente tidos como provimentos de repercussão física, ou seja, se distinguiriam daqueles ditos tradicionais pelo fato de contemplarem o vencedor, na mesma relação processual, com a aplicação de atos executivos expedidos até ex officio, pela própria jurisdição, sem que dependam de um processo autônomo de execução.

Se a condenação prepara a execução e o título executivo é o bilhete de ingresso à atividade estatal sub-rogatória que visa dar cumprimento e satisfação à decisão prolatada em sede cognitiva, na linha de pensamento carneluttiana ${ }^{5}$, esta mesma condenação poderá também, por força de política legislativa, ter efetividade por intermédio de atos subseqüentes dirigidos ao vencido dentro do mesmo processo, resultando uma conseqüência natural da vontade da lei ao caso concreto tutelado, como queria Chiovenda. ${ }^{6}$

\footnotetext{
${ }^{5}$ CARNELUTTI, Francesco. Titolo esecutivo e scienza del processo. Rivista di diritto processuale civile, Milano, Giuffrè, 1934, p. 14

${ }^{6}$ CHIOVENDA, Giuseppe. Instituzioni di diritto procesual civile, Napoli, Jovene, 1933, p. 230, sustentando que a condenação não é, em verdade, com respeito à parte vencida, um ato autônomo de vontade do juiz, não é
} 
Muito mais do que preparar a execução, a condenação nesse sentir operar-se-ia com eficácia plena, sem demandar atos de outro processo autônomo para buscar operacionalidade.

A técnica legislativa pode muito bem empregar diversas formas processuais visando efetivo cumprimento de decisões jurisdicionais sem que se crie ou se transforme o conteúdo da decisão que se busca efetivar, dando-lhe um suposta natureza jurídica diversa, pois em vista de uma eficácia que é ditada pela própria lei, e não pelo magistrado, o conteúdo da decisão proferida, juridicamente se completa, mas não se modifica. ${ }^{7}$

A lei n. 11.232/05 teve por objetivo propiciar uma melhor atuação da lei ao caso concreto em vista da excessiva inefetividade que apresentava a formatação processual destinada à execução por quantia certa contra devedor solvente.

Assim sendo, redefinindo estruturalmente os conceitos de institutos processuais e sistematizando de maneira mais efetiva todo o iter por que caminha a pretensão inicial para chegar à sua efetiva satisfação, na mesma relação processual, redefiniu o legislador parâmetros de efetividade, mas não de conteúdo ou natureza jurídica, pois a nova sistemática do cumprimento de sentença continua a manter como objeto principal do núcleo da decisão jurisdicional que se faz cumprir, uma obrigação não adimplida e, por suposto, ensejando o ideal condenatório. ${ }^{8}$

Tradicionalmente a condenação prepara a execução por mera vontade legislativa e, claro, por razões históricas que advém da formatação processual romana marcada pela actio iudicati, mas não é esta característica, a nosso ver, contrariando inclusive tradicional doutrina, que determina a natureza jurídica de uma sentença como condenatória.

uma ordem do juiz; é a formulação de uma ordem contida na lei, e só é ato de vontade do juiz neste sentido, de que o juiz queira formular a ordem da lei.

7 Assim conclui BAPTISTA DA SILVA, Ovídio. Curso de Processo Civil: processo de conhecimento, 4.ed., São Paulo, RT, 1998, vol 1, p. 172-173, advertindo que "na sentença de condenação, não há verdadeiramente uma ordem imposta pelo juiz ao condenado, cuja desobediência lhe acarretasse alguma sanção. A 'ordem' que porventura se veja na sentença condenatória, está antes na lei e não na sentença. O juiz, em verdade, ao condenar, limitar-se-á a reproduzir e concretizar uma obrigação já existente e constante da lei.”

${ }^{8}$ Essa é a posição de Cássio Scarpinella Bueno, Ensaio sobre o cumprimento das sentenças condenatórias, RePro n.. 113, Revista dos Tribunais, p. 27, que comentando as características de uma sentença condenatória sustenta que "há autores que negam - e sempre negaram - que uma sentença que mande alguém, fazer ou nãofazer ou entregar alguma coisa seja, propriamente, condenatória. Em tempos mais recentes há aqueles que negam ser esta sua natureza, rotulando-a de executiva ou mandamental. Mais: para alguns, como decorrência desta última afirmação, existe acesa polêmica na doutrina quanto a uma sentença que estabelece um facere, non facere ou um dare poder cumprir-se por processo de execução.” 
Se é a carga preponderante da atividade jurisdicional dada perante a sentença prolatada que caracterizará sua natureza jurídica, segundo Pontes de Miranda, então, é essa `força maior`que nas condenatórias permitirá sua classificação.

E qual a carga imperativa de uma sentença condenatória?

Será a obrigação reconhecida pelo juízo e a determinação de seu adimplemento associada à ausência de atividade executiva posterior demandando assim execução exintervalo?

Se o núcleo da decisão se volta ao pedido efetivado pelo Autor, veremos que é exatamente este núcleo que imprimirá a imposição estatal que exalta em uma condenação, consubstanciada em uma obrigação a ser cumprida, pois esta é a vontade da lei aplicada ao caso concreto pelo Estado que determina a sentença.

A forma de cumprimento desta vontade caracteriza-se como atividade complementar e conseqüência da atividade principal já operacionalizada pela jurisdição, qual seja, a de condenar o vencido no cumprimento de sua obrigação, traduzindo-se a execução e os meios por ela efetivados, sejam diretos ou indiretos, como efeitos jurídicos práticos derivados da condenação. ${ }^{9}{ }^{10}$

A atividade executiva conseqüente da condenação pode ser dada tanto internamente à relação processual onde foi reconhecida ou mediante a formatação de nova relação processual, agora autônoma, buscando especificamente a satisfação da decisão prolatada.

Em ambos os sentidos, a operacionalização destas atividades dependem da vontade legislativa, pois se o legislador pretender maior celeridade e efetividade à forma de realização do direito reconhecido, poderá, como no caso o fez, diante da nova sistemática de

\footnotetext{
${ }^{9}$ É a denominada 'causa' e conseqüente 'efeito' que faz menção Barbosa Moreira, Conteúdo e efeitos da sentença: variações sobre o tema, p. 7-8, afirmando que "é natural que se estabeleça relação íntima entre o conteúdo e os efeitos de um dado jurídico. O ordenamento atribui a cada ato jurídico, em princípio, efeitos correspondentes ao respectivo conteúdo, sem embargo da possibilidade de que, eventualmente, se atribuam efeitos iguais a atos de diferentes conteúdos, ou vice-versa. Para admitir a correspondência não é preciso ver entre o ato jurídico e os efeitos que ele produz, ou pode produzir, nexo de causalidade semelhante ao que existe entre um fato natural e suas conseqüências. Substitua-se o conceito de causalidade, neste âmbito pelo de imputação, e continuará verdadeiro o princípio de que depende do conteúdo do ato o serem tais ou quais os efeitos deste.”. Ver também Casio Scarpinella Bueno, op. cit., p. 64

${ }^{10}$ Assim sendo, "com efeito, ao reconhecer-se o inadimplemento de qualquer obrigação e ordenar-se, judicialmente, ao devedor que se submeta à sanção definitiva pela sentença, dúvida não há mais a respeito da necessidade de realizar-se a atuação da responsabilidade patrimonial. Por isso, a intimação do vencido para pagar e a sujeição à penhora, à apreensão do bem devido, assim como os demais atos executivos, só podem ser encarados como consectários lógicos e necessários da própria condenação, nada havendo a justificara exigência de submeter o credor aos percalços de um novo processo para atingir aquilo que desde a propositura da ação de cognição já era seu único objetivo, qual seja, o de receber o que lhe é devido" (A execução de sentença e a garantia do devido processo legal, Aide, 1987, p. 238 )
} 
execução civil relativa às obrigações de pagamento de quantia certa, instrumentalizar atos que dêem a exata forma de realizar a vontade da lei aplicada ao caso concreto derivada de uma decisão de natureza condenatória. ${ }^{11}{ }^{12}$

Assim também fez o legislador quando modificou em 1995 e em 2002, a sistemática do cumprimento de sentenças que reconheciam uma obrigação de fazer, nãofazer e de entrega de coisa, respectivamente, na forma dos art.s 461 e 461-A do CPC, não se alterando seu conteúdo condenatório ao nosso ver. ${ }^{13}$

Tanto que com o advento da nova legislação, veio simplesmente a ratificar tal intenção no tocante a estas obrigações, quando se fez inserir o novo art. 475 - I do CPC.

O reconhecimento de que a eficácia executiva do cumprimento de sentença tem derivação condenatória, encontra-se pautado dentro do novo contexto legislativo que após 23.06.2006 passou a vigorar em todo o país, dispondo o art. 475 - J que:

Caso o devedor, condenado ao pagamento de quantia certa ou já fixada em liquidação, não o efetue no prazo de quinze dias, o montante da condenação será acrescido de multa no percentual de dez por cento e, a requerimento do credor e observado o disposto no art. 614, inciso II, desta Lei, expedir-se-á mandado de penhora e avaliação.

Diante do texto legal verificamos que o legislador insiste em falar em condenação, mas agora dando especial tratamento relativo à fase executiva da relação processual, criando uma sistemática mais efetiva para a prática dos atos de satisfação.

A grande questão-chave que determinará se a natureza jurídica da decisão que se passa agora a executar é condenatória ou executiva lato sensu tem ligação com um aspecto

${ }^{11}$ Em vista disso alerta MURITIBA, Sérgio. Ação Executiva Lato Sensu e Ação Mandamental, São Paulo: RT, 2005, p. 217-256, que a técnica condenatória foi especialmente construída para atender os deveres de dar quantia e foi historicamente moldada para veicular pretensões pecuniárias de cunho ressarcitório, que tinha no meio executório da expropriação o instrumento ideal. À exceção de uma proposta legislativa de emprego de técnicas executivas diretas quando a quantia em dinheiro fosse encontrada in natura, todas as demais hipóteses que acabam por exigir a expropriação e, por suposto, mais tempo, novos atos e operações, a exemplo da penhora, da avaliação e da arrematação ou adjudicação, diminuiriam a eficiência da técnica executiva lato sensu ou mandamental às situações substanciais que envolvam deveres de pagamento de quantia certa, sendo caracteristicamente tal atividade processual marcada pela eficácia de uma sentença condenatória.

${ }^{12}$ Cassio Scarpinella Bueno, Ensaio sobre o cumprimento das sentenças condenatórias, op. cit., p. 30

${ }^{13}$ idem, op. cit., p. 32-33, identificando que "o que ocorre nestas ações do art. 461-A é , nada mais e nada menos, do que autorizar o juiz, em um mesmo processo, sem solução de continuidade, a declarar a existência de direitos e realizar concretamente esta declaração desde pronto, independentemente de como esta realização concreta vai se dar. Friso: Não há nada de extraordinário para o direito brasileiro em relação a isto: nas cautelares isto sempre ocorreu, idem nos despejos, nas possessórias, nos mandados de segurança e a bem da verdade, em boa parte dos denominados 'procedimentos especiais' [...] Os dois dispositivos, de resto, outorgam ao juiz aplaudidos ‘deveres-poderes' para bem atingir a 'tutela específica' ou o 'resultado prático equivalente, entendidas estas expressões como a amáxima coincidência possível entre o cumprimento jurisdicional e o préjurisdicional da obrigação, isto é, caso não fosse necessário o ingresso no Judiciário, do o cumprimento espontâneo do vínculo obrigacional.” 
prático não muito bem explicitado pela nova legislação, qual seja, o do momento de início do cumprimento de sentença.

Em uma leitura idealista, tal como apresentada na exposição de motivos do Projeto e Lei que deu origem à lei n. 11.232, verificamos que a proposta inovadora da nova sistematática da execução civil no país é de iniciar o cumprimento de sentença sem qualquer manifestação do credor ou propositura de eventual ação autônoma, desfazendo a estrutura dualista até então existente sob o principal argumento da celeridade e da efetividade processual.

Assim sendo, teríamos o que a doutrina já vem denominando de cumprimento 'ex officio', ou imediato, pois uma vez transitada a decisão que reconhece a obrigação de pagamento de soma em dinheiro, automaticamente, se abriria a contagem do prazo de quinze dias para que se efetive o cumprimento voluntário da referida obrigação, sob pena de ser incidida multa no valor de $10 \%$ (dez por cento) a ser acrescida ao valor principal da condenação, a ser imposta a partir do décimo sexto dia, ou exatamente, do primeiro dia após o decurso do prazo legal dirigido ao vencido, conforme o art. 475-J do Código de Processo Civil. $^{14}$

Somente após decorrido esse prazo, e da atividade ex officio desenvolvida pelo juiz, arbitrando a multa, teríamos a presença do credor, que daria prosseguimento ao cumprimento, requerendo a expedição de mandado de penhora e avaliação e apresentando sua conta, na forma da parte final do mesmo diploma legal. Achados os bens suficientes para iniciar-se a fase de expropriação e satisfação, e efetivado o auto de penhora, o advogado do devedor restará intimado para a apresentação de eventual impugnação, na forma do parágrafo primeiro do art. 475-J.

\footnotetext{
${ }^{14}$ Nesse sentido Athos Gusmão Carneiro, "Do cumprimento da sentença conforme a lei n. 11.232/2005. Parcial retorno ao medievalismo? Por que não?” in Novas Reformas do Código de Processo Civil, Revista do Advogado, AASP, 2006, p. 23, sustentando que "assim, na sentença condenatória por quantia líquida (ou na decisão de liquidação de sentença), a lei alerta para o tempo iudicati de quinze dias, concedido para que o devedor cumpra voluntariamente sua obrigação. Tal prazo passa automaticamente a fluir, independentemente de qualquer intimação, da data em que a sentença (ou o acórdão, CPC, art.512) se torne exigível, quer por haver transitado em julgado, quer porque interposto recurso sem efeito suspensivo.” Essa é a posição de Humberto Theodoro Jr., As novas Reformas do Código de Processo Civil, op. cit., p. 145, afirmando que "é do trânsito em julgado que se conta dito prazo, pois é daí que a sentença se torna exequível. Se porém, o recurso pendente não tiver efeito suspensivo, e, por isso, for cabível a execução provisória, o credor poderá requerê-la com as cautelas respectivas, sem entretanto, exigir a multa. Se o trânsito em julgado ocorre em instância superior (em grau de recurso), enquanto os autos não baixarem à instância de origem, o prazo de quinze dias não correrá, por embaraço judicial. Será contado a partir da intimação das partes, da chegada do processo ao juízo da causa."
} 
Será que então, toda a sentença que condene o devedor a pagar quantia certa deverá trazer em sua parte dispositiva o corte na base da legitimidade (que preponderantemente justificaria a eficácia executiva lato sensu), a determinação do pagamento ‘atualizado’ da dívida dentro do prazo de 15 dias após o seu trânsito em julgado?

Seria essa determinação judicial o tal corte a que se refere a doutrina e que justificaria a eficácia executiva da decisão?

Por suposto, dentro deste raciocínio, o início do cumprimento se daria imediatamente, dependendo, claro, da vontade do vencido em adimplir voluntariamente a decisão proferida, em obediência à decisão jurisdicional, que verificando o não pagamento no prazo legal, imporia atos de coerção e posterior sub-rogação, com a conseqüente imposição da multa e de penhora e avaliação de bens voltados à efetivação do decisum. ${ }^{15}$

Essa foi a proposta que está consignada na exposição de motivos do Anteprojeto da lei n. 11.232/05 quando propugna a imediata satisfação da decisão jurisdicional, permitindo a efetiva entrega do bem da vida pretendido.

Teoricamente seria fantástico, mas na prática, verificamos que algumas circunstâncias impediriam a operacionalidade da respectiva norma que não se efetivaria da forma como eventualmente quis o legislador, senão vejamos.

Pois bem, se na decisão judicial que será objeto do respectivo cumprimento haveria determinação para pagamento de soma em dinheiro, deveria a mesma explicitar a determinação de um pagamento pelo vencido devidamente atualizado, dentro do prazo legal de cumprimento voluntário, bem como, o índice a ser utilizado e o acréscimo de verbas de sucumbência, além do alerta dirigido ao devedor de que diante de eventual inadimplemento

${ }^{15}$ Esse é o pensamento de TORRES DE MELLO, Rogério Licastro, A defesa na nova execução de título judicial’ in Processo de Execução Civil: Modificações da Lei n. 11.232/05. São Paulo: Quartier Latin, 2006, p. 288-289, apontando que "de acordo com a estrutura típica das sentenças executivas lato sensu, a intimação do réu a cumprir a condenação advém do próprio dispositivo da sentença, ou seja, é do ato do juiz e, vez publicada a sentença, tal ato já se vê consumado. A hipótese mais exemplificativa que encontramos advém das sentenças de procedência das ações de despejo por falta de pagamento: 'julgada procedente a ação de despejo, o juiz fixará prazo de trinta dias para a desocupação voluntária (lei n. 8.245/91, artigo 63). Percebe-se, destarte, que a ordem de cumprimento do preceito condenatório no regime típico das sentenças executivas lato sensu vem à tona com a simples publicação da sentença no Diário Oficial. A nosso ver, seria esta a conformação natural da fase executiva criada pela lei n. 11.232/05: prolatada a decisão condenatória de quantia certa, por intermédio de sua publicação já se materializa a intimação do devedor para pagar”.Muito embora, admita o autor, logo após, na p. 289, que em havendo interpretação duvidosa da lei relativa aos artigos 475-I, parágrafo segundo e 475-J, parágrafo quinto, no sentido de haver intenção do legislador em deixar a requerimento e promoção do credor os atos de início da fase de cumprimento, associada a indiscutível necessidade de atualização do débito, estaríamos diante da idéia de que o cumprimento da sentença ensejaria requerimento inicial anterior à convocação do executado para pagamento voluntário.” 
da obrigação contida no decisum, estaria o mesmo sujeito à multa de dez por cento prevista na nova lei.

Caso contrário quem fará a conta? O próprio devedor? Ou os autos deverão ser remetidos ao contador do juízo?

Supondo que a decisão não disponha acerca da forma do pagamento, e o devedor apresente a conta errada, pagando a menor com a utilização de cálculos e índices de atualização equivocados, criar-se-ia um incidente de impugnação destes valores uma vez intimado o credor para se pronunciar acerca do pagamento?

Entendemos que a reforma não se efetivou com este intuito, mas pelo contrário, optou o legislador por fugir de eventuais empecilhos que viessem a obstruir o cumprimento, exigindo assim um requerimento do credor para dar início ao cumprimento de sentença.

O legislador delegou ao credor a apresentação dos valores que constituirão a memória de cálculo que servirá de base para a penhora e avaliação na forma do art. 475-J, parágrafo primeiro do CPC, bem como, é a própria lei que impõe prazo de seis meses para o início da execução na forma do parágrafo quinto do art. 475-J, dispondo que "não sendo requerida a execução no prazo de seis meses, o juiz mandará arquivar os autos, sem prejuízo de seu desarquivamento a pedido da parte”, constando também do artigo 475, I, parágrafo segundo, a prescrição legal de que “ao credor é lícito promover” a execução.

E se for interposto recurso contra a decisão prolatada? Sem dúvida, adviria um hiato temporal maior entre a prolação da decisão de primeira instância e o seu trânsito em julgado, após confirmação a sentença pelo Tribunal, após ter negado provimento à Apelação interposta, justificando mais do que nunca uma melhor atualização dos valores que serão objeto do cumprimento.

Muito embora toda a proposta legislativa para o novo processo de execução de sentença seja no sentido de imprimir a denominada eficácia executiva lato sensu, pensamos que ainda permanece a natureza jurídica condenatória do decisum, necessitando-se, por questões práticas e de maior efetividade e organização do iter processual, de um requerimento, simples, mas formal, por parte do credor, para dar início à fase de cumprimento de sentença.

Nesse sentido, em vista de um preciso acompanhamento do advogado do credor, o que é natural nas ações em que foi vencedor seu cliente, poderá o mesmo consultar o trânsito em julgado em cartório, ou ainda desde já, ultrapassado o prazo para interposição de 
eventual recurso, requerer a certificação do mesmo para dar início ao cumprimento da referida decisão.

Mediante petição simples, com fundamento no art. 475-J, requererá o causídico ao juízo competente o cumprimento da decisão transitada em julgado, requerendo a intimação do advogado do devedor, para que tome ciência do início da referida fase, e informe a seu cliente a necessidade de cumprimento voluntário no prazo de quinze dias da obrigação reconhecida pela sentença.

Juntamente a este requerimento, desde já, seria apresentado pelo advogado do credor, anexa à petição, toda a memória de cálculo que exige o art. 475-J combinado com o art. 614, II do CPC, incluindo-se aí, as verbas de sucumbência e os valores relativos ao montante principal já devidamente atualizado. ${ }^{16}$

Sem prejuízo ou embargo, desde já, poderá ser requerido ao final da petição, que caso não cumprida a obrigação voluntariamente pelo devedor, seja imposta 'ex officio'a multa prevista na lei, acrescentando-se $10 \%$ (dez por cento) sobre o valor apurado na memória de cálculo para fins de expedição de mandado de penhora e avaliação, na forma do art. 475-J, parágrafo primeiro do CPC, podendo inclusive, também, na mesma petição, serem informados pelo credor dados de eventuais bens imóveis ou móveis de propriedade do devedor que tenha conhecimento, facilitando assim o cumprimento do mandado de penhora e avaliação pelo Oficial de Justiça.

Assim sendo, não precisará o credor retornar aos autos para requerer a penhora e avaliação, pois já poderá deixar requerida a necessária atuação jurisdicional em petição de início de cumprimento de sentença, passando os demais atos a serem praticados pelo juízo.

\footnotetext{
${ }^{16}$ Comentando com precisão acerca do momento de início do cumprimento de sentença, Daniel Amorim Assumpção Neves, assevera que "o art. 475-J do CPC prevê que o prazo somente começa a tramitar quando a quantia a ser cobrada seja certa, exigindo, evidentemete, uma liquidez da obrigação para que se possa exigir do demandado o pagamento. Conforme a melhor doutrina, liquidez não significa a determinação do valor, mas sua determinabilidade por meros cálculos aritméticos, de forma que, após o reconhecimento do direito na sentença, sempre haverá reajustes para atualização do valor devido, o que se acentua na hipótese de recursos para os órgãos de superposição. E mesmo nos casos em que não há apelação a experiência mostra que entre o momento de prolação da sentença e o momento de início da busca da satisfação do direito haverá um lapso temporal suficiente a exigir a atualização do valor.[...] O que se pretende demonstrar é que o demandante deverá, como ato inicial da fase de cumprimento da sentença que condena o demandado a pagar quantia certa, apresentar um memorial de cálculos, atualizando o valor da condenação até a presente data, única forma possível de se determinar o valor exato da obrigação nesse momento processual. Resta evidente que, uma vez apresentado o descritivo de cálculo nos autos, o demandado deverá ser intimado - na pessoa de seu patrono, como se verá para que tome conhecimento de quanto é o valor atualizado de sua obrigação de pagar quantia até aquele momento, dando-lhe ciência de quanto deverá pagar para que se considere satisfeito o direito do autor."'(Reforma do CPC. leis 11.187/2005, 11.232/2005, 11.276/2006, 11.277/2006 e 11.280/2006. Daniel Amorim Assunção Neves ... [et al.], São Paulo: Revista dos Tribunais, 2006, p. 213-14)
} 
O prazo de cumprimento voluntário, definido na lei em 15 (quinze) dias se iniciará no primeiro dia útil posterior ao dia da publicação da intimação dirigida ao advogado do devedor para cientificar seu cliente no sentido de proceder ao cumprimento voluntário do decisum.

Teremos assim, um requerimento que dará eficácia à sentença, configurando assim, nítida atividade condenatória conseqüente do decisum prolatado.

Muito embora o juízo possa até proceder ao corte na base da legitimidade, dirigindo ao Réu o comando estatal de dar cumprimento a obrigação, a eficácia dos atos somente será bem desenvolvida com a disposição do credor em buscar através de seu requerimento o início dos atos que levarão à obtenção do bem da vida postulado, até porque poderá o mesmo não querer dar início ao cumprimento da sentença, em vista de que a disposição sobre o crédito, por força da lei, pode ser iniciada em até seis meses do trânsito em julgado da decisão, jamais se devendo entender que o cumprimento deva iniciar-se obrigatoriamente, independentemente da vontade credor

Teríamos então condenação sem processo autônomo de execução? Sim, e com atos específicos que formatam uma fase posterior à cognição para melhor permitir a entrega da prestação jurisdicional, sem que se tenha aqui, modificação da natureza jurídica da sentença, mas sim, tão e somente, política legislativa que visa o emprego de meios de subrogação a fim de melhor atender a satisfação dos créditos derivados de condenação de soma em dinheiro. ${ }^{17}{ }^{18}$

Estaríamos diante de uma decisão com projeção processual voltada a uma condenação especial, ou seja, dotada de meios executivos especiais (ditados pelo legislador) posteriores à fase cognitiva, pois de forma mais requintada, estaria o processo cumprindo seus resultados sem postergar a eficácia que deriva do conteúdo para outra relação autônoma, mas ao mesmo tempo, sem se deixar perder a característica da condenação, qual seja, fazer atuar verdadeira execução forçada por substituição da vontade do devedor ao

\footnotetext{
${ }^{17}$ Luis Rodrigues Wambier, Tereza Arruda Alvim Wambier e José Miguel Garcia Medina, em comentários à reforma processual, sustentam que "[...] é prevista uma medida executiva coercitiva ope legis, já que o descumprimento da obrigação reconhecida na sentença condenatória acarretará a incidência de multa de $10 \%$ sobre o valor da condenação. Embora a medida coercitiva citada incida imediatamente, o que permite compreender a referida sentença, quanto a este ponto, como executiva lato sensu, o início da prática de atos de expropriação - penhora, arrematação, etc. - é condicionado pelo art. 475-J do CPC ao 'requerimento do credor'. Assim, embora unificadas procedimentalmente as ações de conhecimento e de execução, a sentença mantém aspecto peculiar que a caracteriza como condenatória: o de depender, para a realização dos atos executivos, de requerimento realizado posteriormente ao seu proferimento, pelo credor." In Breves comentários à nova sistemática processual civil, vol 2, São Paulo, RT, 2006. p. 144.

${ }^{18}$ v. Cássio Scarpinella Bueno, op. cit. , p. 32, sustentando que "sentenças condenatórias podem viver e, de resto, já vivem entre nós, sem processo de execução”.
} 
poder estatal, fazendo-se atuar por meios sub-rogatórios, estabelecendo assim, uma nova visão do cumprimento das decisões condenatórias, dentro dos propósitos do processo sincrético. ${ }^{19}{ }^{2}{ }^{20}$

As fontes históricas trazem precedentes experimentados, sobretudo pelo direito medieval que em muito se assemelham com a sistemática introduzida pela lei n. 11.232/06, em vista que não descaracterizando a natureza jurídica condenatória da decisão prolatada, sem se efetivar nova ação com proposta executiva, ou seja, sem se exigir actio iudicati ao julgado, teríamos, como conseqüência da própria atividade jurisdicional, a eficácia executiva imediata do decisum, permitindo assim, que na mesma relação processual, o julgador, pela competência que lhe foi direcionada em vista do julgar e conhecer, também possa, como efeito da causa, executar, satisfazendo e entregando, sob os meios que dispõe a jurisdição, o bem da vida pretendido pelo credor e reconhecido pelo comando sentencial, que impõe o cumprimento da obrigação, até então não adimplida voluntariamente pelo devedor.

O juiz pode e deve desenvolver atividade executiva direta, pois são conexas ao seu ofício, e como verificamos nos comentários trazidos por Liebman, no sentido de que “o requerimento que provoca a execução, não constitui exercício de uma nova ação, de um novo direito contra a outra parte, mas um simples ato de impulso processual com o fim de provocar a realização concreta dos atos incumbentes aos juizes”. ${ }^{21}$

\footnotetext{
${ }^{19}$ Assim já se pronunciou José Roberto dos Santos Bedaque, Direito e Processo, São Paulo, Malheiros, 1995, p. 102, referindo-se à necessidade de uma mais efetiva tutela das sentenças condenatórias, quando sustenta que "a partir de situações tuteladas de forma mais eficaz pelo legislador, que possibilita a auto-executoriedade de determinadas sentenças condenatórias (despejo, possessórias, alienação fiduciária), passa-se a imaginar a possibilidade de se estender essa técnica a outras hipóteses. Vale a pena meditar inclusive, sobre as vantagens de ma sentença condenatória referente a quantia de prescindir do processo de execução. Bastaria a intimação do réu para cumpri-la em determinado prazo, sob pena de penhora. Seriam ressalvadas, evidentemente, as situações excepcionais (como, por exemplo, a citação ficta no processo cognitivo). Esse raciocínio é válido para todas as espécies de execução.” Tal afirmação também foi ventilada por THEODOR JÚNIOR, Humberto. A execução de sentença e a garantia do devido processo legal, Rio de Janeiro: Aide, 1987, p. 237, pois "embora o que queira de fato o credor seja a concretização efetiva de seu direito, só não é possível, por exemplo, o autor de uma ação de indenização pedir desde logo a condenação do devedor ao pagamento do prejuízo, com a cominação de penhora e praceamento de bens e conseqüente pagamento do que lhe é devido, porque teima em prevalecer o dogma de que o processo de conhecimento e o processo de execução são atividades distintas e que só devem ser tratadas em relações processuais distintas.”

${ }^{20}$ Assim já se manifestava THEODORO JR, Humberto., A execução de sentença e a garantia do devido processo legal, Rio de Janeiro: Aide, 1987, p. 239, com fundamento no pensamento de Pontes de Miranda, posicionando-se no sentido de que "não há razão, no plano lógico, para continuar a considerar, nas ações condenatórias, a força executória como diferida, se nas ações especiais a execução pode ser admitida como parte integrante essencial da própria ação originária. Nossa proposição é que, em se abandonando velhas e injustificáveis tradições romanísticas, toda e qualquer pretensão condenatória possa ser examinada e atendida dentro de um único processo, de sorte que o ato final de satisfação do direito do autor não venha a se transformar numa nova e injustificável ação, como ocorre atualmente em nosso processo civil.”

${ }^{21}$ Liebman, Embargos do Executado, op. cit. p. 84-85 citando a doutrina de Martino de Fano, as críticas à formatação da execução sem o novus processus e as hipóteses trazidas por outros doutrinadores do uso
} 
Não haverá petição inicial, na idéia de se voltar ao sistema processual da dualidade, porque não haverá nova ação para dar cumprimento às sentenças, mas tão e somente, requerimento que provocará e dará as bases que iniciarão o ofício do juiz, preparando a atividade executiva, em vista de que o próprio Código dá essa disponibilidade ao credor nos termos do art. 569.

Assim sendo, a execução da sentença pertencerá ao officium iudicis, ou seja, ao ofício do juiz, por atribuição direta derivada do simples fato de ter julgado a causa.

E é exatamente essa a razão que deriva como fonte do direito medieval que permite o cumprimento de sentenças na mesma relação processual, permitindo a aplicação pelo órgão judicial das medidas que mais sejam eficazes a cada caso concreto em vista do comportamento do devedor, e que já no direito intermédio se demonstrava como forma alternativa de se suprir os defeitos e falhas que apresentava a sistemática da actio iudicati, o que não muda em nada a sistemática até então havida entre nós, pois igualmente apresentava-se como complexa e ineficaz, diante de uma dualidade processual entre cognição e execução que não mais se justificava. ${ }^{22}$

Por toda a longa exposição histórica trazida por Liebman, ao final, reconhece o processualista italiano que “a sentença condenatória, todavia, a mais de conferir ao vencedor a actio iudicati, permite-lhe seguir, como sabemos, procedimento muito mais simples para obter a execução sem um novus processus: por essa via, pode-se atuar o ius executivum diretamente, sem verificação da subsistência do direito de crédito.”23

Com objetivo de permitir uma simplificação e agilização do procedimento, a via adequada nestas circunstâncias para na prática se efetivar o comando judicial é uma petição, postulada pelo credor, sem actio, sem lide, sem libelo, e claro, sem a necessária produção de outra sentença, mas de forma rápida e direta, que se caracterize pelo requerimento de exortar o devedor a cumprir a sentença sob pena de se efetivar preceito que ordena a execução. ${ }^{24}$

específico da actio ou da execução sem intervalo.V. também Humerto Theodoro Jr., As novas Reformas do Código de Processo Civil, op. cit., p. 100-101.

${ }^{22}$ Liebman, Embargos do Executado ..., op. cit., p. 83, assinala que "no uso germânico e especialmente no longobardo, cognição e execução não se apresentavam distintas nem separadas: o procedimento destinado à satisfação do credor constituía um todo unitário, no qual se podia inserir a cognição como um incidente não autônomo , e ao pronunciamento da sentença sucedia diretamente, por obra do próprio juiz, a atividade tendente a obter o adimplemento do devedor, ou, quando menos, análoga promessa em forma solene, sem que, por isso, fosse de mister um requerimento especial do credor, o qual já estava implícito na petição inicial, que objetivava, não uma sentença, senão o resultado, concreto, final, consistente no pagamento do débito ou na restituição da soma ou outra coisa qualquer.”

${ }^{23}$ idem, op. cit., p. 89

24 idem, op. cit., p. 92 
Um processo voltado aos fins a que se propõe, delimitados pela busca incessante da entrega do bem da vida pleiteado desde o início da relação processual, podendo fazer atuar diversas modalidades de tutela de acordo com as circunstâncias fáticas posteriores ao reconhecimento da obrigação, efetivando o respectivo decisum mediante a aplicação de meios executivos sub-rogatórios, mandamentais, de execução forçada, por atividade estatal direta ou indireta, mas sempre, com base em conteúdo condenatório.

Desta forma, o cumprimento das decisões não necessitava e, agora, após a nova legislação processual em vigor, nos moldes do formato medieval, mais ainda, não necessita, da abertura de um processo autônomo, pois cabe ao juiz exercer seu ofício a fim de cumprir a decisão prolatada. ${ }^{25}$

É essa valoração da decisão jurisdicional, em especial, in casu, a sentença condenatória, que permitirá uma completa atuação da jurisdição, pois através da complementação por meios executivos posteriores à condenação prolatada, em fase subseqüente àquela que se efetivou a cognição, é que o processo civil reforça seus propósitos de caminhar mais agilmente e efetivamente rumo à incansável busca da proteção ao direito material. $^{26}$

É sem dúvida, revisão (ou modernamente designada como revisitação) ${ }^{27}$ voltada ao pragmatismo; racionalidade que busca a realização, é forma que quer alcançar o seu fim.

Cabe ao tempo e aos operadores jurídicos demonstrarem que os caminhos traçados pelo legislador serão interpretados com vista ao emprego de uma tipicidade e multiplicidade de atos que possam efetivamente produzir os propósitos a que todo processo se destina, a verdadeira entrega da pretensão de direito material representada pelo bem da vida perquirido pelo vencedor da demanda.

\footnotetext{
${ }^{25}$ Humberto Theodoro Jr., As novas reformas do Código de Processo Civil, op.cit., p. 104, assinala que "em pleno século XXI, voltou-se a presenciar o mesmo fenômeno da Idade Média: o inconformismo com a separação da atividade jurisdicional de cognição e de execução em compartimentos estanques, e a luta para eliminar a desnecessária figura da ação autônoma de execução de sentença (a velha actio iudicati do direito romano)"

${ }^{26}$ Nesse sentido, Cândido Dinamarco, Execução Civil, Malheiros, 1997, p. 133, observando que não há desnaturação da natureza jurídica condenatória de uma sentença que se sucede de atos executivos na mesma relação processual, considerando inútil e desnecessário rotular de 'executiva' a referida decisão pelo fato de o processo seja um só. E já admitia à época da publicação que há nesse sentido sincrético relevante significado político, na medida em que o exercício da função pública jurisdicional ficaria liberto do condicionamento a nova iniciativa do demandante. "Tem significado positivo, também, em relação ao escopo pacificador que lhe move o Estado a exercer a jurisdição, uma vez que lhe permitiria chegar de modo menos complicado e moroso à consumada eliminação dos litígios.”

${ }^{27}$ V. Ada Pellegrini Grinover, Candido Dinamarco, dentro da idéia de revisão dos conceitos processuais com finalidade e busca de efetividade processual.
} 
A incansável busca de efetividade com base nos propósitos lançados pela nova sistemática da execução civil também deve ter respaldo na vontade política e administrativa dos operadores do direito e do Poder Judiciário, pois sem um perfeito aparelhamento infraestrutural que possa responder aos anseios e propósitos da lei, teremos sem dúvida, a total ineficácia da tutela jurisdicional que tanto se almeja, restando inefetiva toda a modificação legislativa trazida com as novas reformas processuais.

Artigo recebido em fevereiro de 2007

Aceito para publicação em abril de 2007

\section{Referências}

BARBOSA, José Carlos Moreira. Temas de Direito Processual. $8^{\mathrm{a}}$ Série, São Paulo: Saraiva, 2004.

BEDAQUE, José Roberto dos Santos. Direito e Processo. $1^{\text {a }}$ ed., São Paulo: Malheiros, 1995.

BUENO, Cássio Scarpinella, Ensaio sobre o cumprimento das sentenças condenatórias, Revista dos Tribunais. São Paulo, v.29 n.113 jan. / fev. 2004

CARNELUTTI, Francesco. Titolo Esecutivo e Scienza Del Processo. Rivista Di Diritto Processuale Civile. Milano: Giuffrè. 1934. p. 14.

CARNEIRO, Athos Gusmão. Do cumprimento da sentença conforme a lei n. 11.232/2005. Parcial retorno ao medievalismo? Por que não? Revista Dialetica De Direito Processual (Rddp), n.38, maio / 2006, p. 23

CHIOVENDA, Giuseppe. Instituzioni Di Diritto Procesual Civile. 2 ed., Napoli: 1950.

DINAMARCO, Cândido Rangel. Execução Civil. 8ª ed., São Paulo: Malheiros, 2002.

LIEBMAN, Enrico Tullio. Embargos do Executado. São Paul: Saraiva 1952

MURITIBA, Sérgio. Ação Executiva Lato Sensu e Ação Mandamental. São Paulo: Revista dos Tribunais, 2005.

NEVES, Daniel Amorim Assumpcao; RAMOS, Glauco Gumerato e FREIRE, Rodrigo Da Cunha Lima. Reforma do CPC. leis 11.187/2005, 11.232/2005, 11.276/2006, 11.277/2006 e 11.280/2006. São Paulo: Revista dos Tribunais, 2006.

PROTO, Pisani. Lezioni Di Diritto Processuale Civile, 3ª.ed., Napoli: Jovene, 1999.

SILVA, Ovídio Araújo Baptista da. Curso de Processo Civil: processo de conhecimento. $4^{\mathrm{a}}$ ed., vol 1. São Paulo: Revista dos Tribunais, 1998. 
THEODOR JUNIOR., Humberto. Curso de Direito Processual Civil. 27 ed, v.1, Rio de Janeiro: Forense, 2000.

As novas Reformas do Código de Processo Civil: leis 11.187 de 19/10/2005, 11.232 de 22/12/2005, 11.276 e 11.277 de 07/02/2006 e 11.280 de 16/02/2006 . $1^{\mathrm{a}}$ ed., $5^{\mathrm{a}}$ tiragem. Rio de Janeiro: Forense, 2007.

Janeiro: Aide, 1987.

A execução de sentença e a garantia do devido processo legal. Ed.?, Rio de

TORRES DE MELLO, Rogério Licastro. A Defesa na Nova Execução de Título Judicial, in Processo de Execução Civil: Modificações da Lei n. 11.232/05. São Paulo: Quartier Latin, p. 288-289, 2006.

WAMBIER, Luis Rodrigues; ALVIM WAMBIER, Tereza Arruda e GARCIA MEDIAN, José Miguel. Breves Comentários à Nova Sistemática Processual Civil. vol 2, São Paulo: Revista dos Tribunais, 2006.

\section{Resumo}

Trata-se de artigo que aborda a natureza jurídica do cumprimento de sentença, avaliando as conseqüências trazidas pela nova sistemática processual de execução das sentenças cíveis com base na lei n. 11.232/06, apontando as posições doutrinárias que conduzem ao entendimento de que as eficácias jurídicas de executividade lato sensu e mandamentalidade são derivadas da condenação como categoria de sentença proferida no processo civil brasileiro.

Palavras-chave: Cumprimento de sentença. Condenação. Natureza jurídica. Executividade latu sensu.

\begin{abstract}
This article approaches the juridical nature of the fulfillment of a sentence, analyzing the consequences brought by the new procedural systematic of civil sentences' execution based on law n. 11.232/06, pointing out the doctrinal positions that lead to the understanding that the juridical effectiveness of lato sensu executivity and obligations are derived of conviction as a category of sentences rendered in Brazilian’s civil procedural law.
\end{abstract}

Keywords: Fulfillment of sentence, conviction, juridical nature, latu sensu executivity. 